\title{
STUDY OF PREVALENCE OF DIABETES MELLITUS TYPE-2 AND IMPAIRED GLUCOSE TOLERANCE AMONG ADULTS IN A RURAL AREA OF KATIHAR, BIHAR
}

\author{
Sazid Hussain ${ }^{1}$, Mohammad Intekhab Alam Chand², Mukesh Nandan³ \\ 1 Junior Resident, Department of Community Medicine, Katihar Medical College, Katihar, Bihar. \\ ${ }^{2}$ Assistant Professor, Department of Community Medicine, Katihar Medical College, Katihar, Bihar. \\ ${ }_{3}^{3}$ Assistant Professor, Department of Community Medicine, Katihar Medical College, Katihar, Bihar.
}

\section{ABSTRACT}

The prevalence of type-2 diabetes mellitus is increasing globally particularly in developing countries. Previously, diabetes mellitus type- 2 was disease of middle aged and elderly, but recently it is affecting younger age group including adolescents especially in the high risk population.

\section{OBJECTIVES}

1. To determine the prevalence of diabetes mellitus type-2 in a rural population of age 30 years and above,

2. To determine the prevalence of Impaired Glucose Tolerance in a rural population of age 30 year and above, and

3. To study the association of various risk factors with diabetes mellitus type- 2 and Impaired Glucose Tolerance.

\section{METHODOLOGY}

A community-based cross-sectional study was carried out in population 30 years and above at Chanpi village in the district of

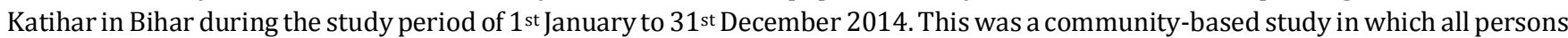
aged 30 years or more living in this village were eligible for participation. After taking early morning fasting sample, the study subjects were given $75 \mathrm{gm}$ of anhydrous glucose in $200 \mathrm{~mL}$ of water to drink in 5 minutes and blood samples were collected exactly after 2 hours to estimate oral glucose tolerance. Samples were tested in the laboratory on the same day.

\section{RESULTS}

Total sample size in this study was 916 and out of this 31 were found to have type-2 diabetes mellitus and 75 were Impaired Glucose Tolerance (IGT). Distribution of type 2 diabetes among non-vegetarians was found to be $77.42 \%$ and $85.33 \%$ in IGT. 54.84\% males and $45.16 \%$ females were found to be type- 2 diabetes mellitus and almost same percentage of males and females were found in IGT. Distribution of DM-2 according to literacy level was found to be $29.03 \%, 41.94 \%, 19.35 \%, 6.45 \%, 3.23 \%$ are illiterate, just literate, primary, secondary, higher secondary school person respectively.

\section{CONCLUSIONS}

This study shows that the prevalence of diabetes and IGT is high in the subjects having sedentary lifestyle, non-vegetarians, and illiterates. Control of DM and IGT mandates lifestyle modification and control of risk factors.

\section{KEYWORDS}

Impaired Glucose Tolerance (IGT), Diabetes Mellitus, Physical Activity, Dietary Habits, Literacy.

HOW TO CITE THIS ARTICLE: Hussain S, Chand MIA, Nandan M. Study of prevalence of diabetes mellitus type-2 and impaired glucose tolerance among adults in a rural area of Katihar, Bihar. J. Evolution Med. Dent. Sci. 2016;5(54):3619-3623, DOI: $10.14260 /$ jemds/2016/834

\section{INTRODUCTION}

The prevalence of type-2 diabetes mellitus is increasing globally particularly in developing countries. ${ }^{1,2}$ In India, it is estimated that over 65 million people have type- 2 diabetes mellitus making it the country with the second highest number of cases behind only China.2,3 It is projected that nearly 110 million people in India will have type-2 diabetes mellitus by 2035. ${ }^{2}$ In a study, Danaei et al reported that globally, as of 2013, an estimated 347 million people had diabetes mellitus. ${ }^{4}$ The first multicentric population-based study in India was done by the ICMR between 1972 and 1975 reported a

Financial or Other, Competing Interest: None.

Submission 26-05-2016, Peer Review 22-06-2016,

Acceptance 27-06-2016, Published 05-06-2016.

Corresponding Author:

Dr. Sazid Hussain,

Junior Resident,

Department of Community Medicine,

Katihar Medical College,

Katihar, Bihar.

E-mail: sazidhussain709@gmail.com

DOI: $10.14260 /$ jemds/2016/834 prevalence of $3 \%$ of urban area and $1-3 \%$ in rural area. ${ }^{5}$ Recent evidence points to an increase in diabetes is even in rural areas and that the pre-diabetic condition, which is characterized by IGT occurs as frequently as in urban populations. This presents a worrying scenario in rural and small town populations, which will probably result in an even higher burden of the disease in the future. ${ }^{6}$ Patient with T2DM in India generally develop the disease at a younger age than those in other parts of the world. In developed Country, disease develop at 65 yrs. and after 65 yrs. and compared to developing countries it is 45-65 yrs. ${ }^{7,8}$ An upsurge in number of early onset diabetes cases is also responsible for the development of various diabetic complications due to longer disease duration, however, data on the prevalence on diabetic complications across the whole of India is scarce. ${ }^{9,10}$ A recent international study reported that diabetes control in individuals worsened with longer duration of the disease (9.9 \pm 5.5 years). ${ }^{9}$

Impaired Glucose Tolerance (IGT) and Impaired Fasting Glucose (IFG) collectively called as pre-diabetic states have a high risk of conversion to diabetes. Several studies have shown 
that these pre-diabetic states are also high risk stages for cardiovascular disease. Majority of population-based studies reported similar prevalence of diabetes in the males and females.

The early identification of those person who are at-risk and appropriate intervention to increase physical activity, decreased central adiposity, and changes in dietary habits could do a great extent help in preventing or delay in the onset of diabetes mellitus and thus reduce the burden due to its associated complications in India. There is also a need to improve knowledge and awareness about diabetes mellitus in rural as well as urban areas through various IEC activities. The objectives of the present study were (1) To determine the prevalence of diabetes mellitus type- 2 in a rural population of age 30 years and above, (2) To determine the prevalence of Impaired Glucose Tolerance in a rural population of age 30 years and above, and (3) To study the association of various risk factors with diabetes mellitus type- 2 and Impaired Glucose Tolerance.

\section{METHODOLOGY}

A community-based cross-sectional study carried out in population 30 years and above at Chanpi village in the district of Katihar, Bihar during the study period $1^{\text {st }}$ January to $31^{\text {st }}$ December 2014. Chanpi village with population of approximately 15,000 is a rural field practice area of Katihar Medical College, Katihar. The distance of Chanpi village from Katihar Medical College is 12 kilometres. Voluntary written consent was obtained from all subjects and prior permission was obtained from the Institutional Ethics Committee for the study.

The prevalence of type- 2 diabetes mellitus in rural population of India is $2.4 \%$ reported by WHO. Based on this, the sample size is calculated by adopting the formula:

$$
\mathbf{n}=\frac{\mathbf{Z}^{2} \boldsymbol{\alpha}^{1 / 2} \times \mathbf{P Q}}{\mathbf{\Sigma}^{2}}
$$

Where $\mathrm{P}=$ prevalence rate of the disease,

Here $\mathrm{p}=2.4 \%=0.024$

$\mathrm{Q}=1-\mathrm{P}=$ complement of $\mathrm{P}$,

Here $Q=97.6 \%=0.0976$

$\sum=$ Allowable error $20 \%$ of $\mathrm{P}=0.048$

$\alpha=$ Level of significance (Type I error)

$\mathrm{Z} \alpha / 2=1.96=2(\alpha=0.05) \mathrm{z}^{2}=4$

$\Sigma^{2}=(0.048)=0.002304$

After adopting this formula with degree of confidence, 95\% the total sample size was calculated to be 916 .

The number of houses in this village is approximately 2500. Houses that are having at least one or more person of age 30 years and above were numbered serially. This was a community-based study in which all persons aged 30 years or more living in this village were eligible for participation. Then, house survey was undertaken by systematic random sampling technique. To select the household, systematic random sampling was done. A list of the household was made in all the selected areas.

Thereafter, a random number was chosen as the first household and subsequently every alternate household was selected.
The final sample includes 916 individuals with 467 men and 449 women after selective screening methodology. Thus, 916 subjects of age 30 year and above were interviewed in the selected houses after establishing good rapport. The different variable for this study have been taken as follows: Age, Sex, Education, Occupation, Physical activity, Dietary habit, literacy, etc. All the information was recorded in the predesigned and pre-tested schedule. Clinical examination was also done. The participants were then requested to remain fasting (For at least $8 \mathrm{hrs}$.) on next morning for venous blood sample collection. After taking early morning fasting sample of venous blood, 75 gm of anhydrous glucose was given in 200 $\mathrm{mL}$ of water to drink in 5 minutes. Exactly after 2 hours of taking glucose, the venous blood was taken to estimate oral glucose tolerance.

Blood was tested in the laboratory on the same day. Consent was taken before taking blood samples and the objective of the study clearly explained in local language to the subjects. Samples were tested in the laboratory on the same day by glucose oxidase-peroxidase method. The participants were informed about the result of the blood test and necessary advice was given and referral was done to our Medical College for further management, if needed. Results were analysed as per WHO criteria. Chi Square $\left(\chi^{2}\right)$ was calculated manually for statistical analysis. The cut off values was used for a subject as diabetes and IGT are:

\begin{tabular}{|c|c|c|}
\hline Particulars & $\begin{array}{c}\text { Fasting plasma } \\
\text { glucose }\end{array}$ & $\begin{array}{c}\text { 2 hrs. after } \\
\text { glucose load }\end{array}$ \\
\hline Diabetes Mellitus & $>126 \mathrm{mg} / \mathrm{dL}$ & $>200 \mathrm{mg} / \mathrm{dL}$ \\
\hline Impaired Glucose & $110 \mathrm{mg} / \mathrm{dL}-$ & $140 \mathrm{mg} / \mathrm{dL}-$ \\
Tolerance & $126 \mathrm{mg} / \mathrm{dL}$ & $200 \mathrm{mg} / \mathrm{dL}$ \\
\hline
\end{tabular}

\section{OBSERVATION AND RESULTS}

In the present study, the total sample size was 916 and out of these $31(3.38 \%)$ was diagnosed as type-2 diabetes mellitus and $75(8.18 \%)$ subjects were found to be impaired glucose tolerance.

\begin{tabular}{|c|c|c|c|}
\hline Age Group & Male & Female & Total \\
\hline $30-40$ & 76 & 74 & $\begin{array}{c}150 \\
(16.37 \%)\end{array}$ \\
\hline $41-50$ & 217 & 216 & $\begin{array}{c}433 \\
(47.27 \%)\end{array}$ \\
\hline $51-60$ & 145 & 132 & $\begin{array}{c}277 \\
(30.24 \%)\end{array}$ \\
\hline $61-70$ & 29 & 27 & $\begin{array}{c}56 \\
(6.12 \%)\end{array}$ \\
\hline Total & $\begin{array}{c}\mathbf{4 6 7} \\
\mathbf{5 0 . 9 8 \% )}\end{array}$ & $\begin{array}{c}\mathbf{4 4 9} \\
(\mathbf{4 9 . 0 2} \%)\end{array}$ & $\begin{array}{c}\mathbf{9 1} 6 \\
(\mathbf{1 0 0 . 0} \%)\end{array}$ \\
\hline \multicolumn{4}{|c|}{ Table 1: Distribution of Total Study Subjects } \\
According to Age
\end{tabular}

Out of 916 subjects, 150 (16.37\%) are in the age group of 30-40 years, in 41-50 years, there are 217 male and 216 female, total 433 (47.27\%), among 51-60 years, there are total $277(30.24 \%)$ subjects and in $61-70$ years $51(6.12 \%)$ subjects. [Table 1]. 


\begin{tabular}{|c|c|c|c|}
\hline Age Group & Type-2 DM & Normal & Total \\
\hline \multirow{2}{*}{$30-40$} & $\begin{array}{c}2 \\
(6.45 \%)\end{array}$ & $\begin{array}{c}135 \\
(16.65 \%)\end{array}$ & $\begin{array}{c}137 \\
(16.27 \%)\end{array}$ \\
\hline \multirow{2}{*}{$41-50$} & $\begin{array}{c}9 \\
(29.03 \%)\end{array}$ & $\begin{array}{c}405 \\
(49.94 \%)\end{array}$ & $\begin{array}{c}414 \\
(49.17 \%)\end{array}$ \\
\hline \multirow{2}{*}{$51-60$} & 15 & 227 & 242 \\
& $(48.39 \%)$ & $(27.99 \%)$ & $(28.74 \%)$ \\
\hline $61-70$ & $5(16.13 \%)$ & $44(5.42 \%)$ & $49(5.82 \%)$ \\
\hline Total & $\mathbf{3 1}$ & $\mathbf{8 1 1}$ & $\mathbf{8 4 2}$ \\
& $(\mathbf{1 0 0} \%)$ & $\mathbf{( 1 0 0 \% )}$ & $\mathbf{( 1 0 0 \% )}$ \\
\hline
\end{tabular}

Table 2: Comparison of Type-2 DM Subjects with Normal Subjects Among Different Age Group

In the age group of 30-40 years, there were 137 subject and out of this only 2 subjects (1.46\%) suffering from type-2 diabetes mellitus. Similarly, in the age group of 41-50 years, there were 414 subjects and out of these 9 (2.17\%), in 51-60 years age group total 242 subjects and out of these 15 (6.18\%) and in the 61-70 years total 49 subject and out of these 5 $(10.21 \%)$ were suffering from type-2 diabetes mellitus. As the age increases, the percentage of type- 2 diabetes increases, which is statistically significant after Yates' correction $p<0.05$, $\chi^{2}$ test is $13.616, \mathrm{df}-3$.

\begin{tabular}{|c|c|c|c|}
\hline $\begin{array}{c}\text { Physical } \\
\text { Activity }\end{array}$ & Type-2 DM & Normal & Total \\
\hline Sedentary & $\begin{array}{c}14 \\
(45.16 \%)\end{array}$ & $\begin{array}{c}209 \\
(25.77 \%)\end{array}$ & $\begin{array}{c}223 \\
(26.48 \%)\end{array}$ \\
\hline Mild & 8 & 365 & 375 \\
$(25.81 \%)$ & $(45.01 \%)$ & $(44.54 \%)$ \\
\hline Moderate & 5 & 203 & 208 \\
$(16.13 \%)$ & $(25.03 \%)$ & $(24.70 \%)$ \\
\hline Heavy & 4 & 34 & 36 \\
$(12.90 \%)$ & $(4.19 \%)$ & $(04.28 \%)$ \\
\hline Total & $\begin{array}{c}\mathbf{3 1} \\
(100 \%)\end{array}$ & $\begin{array}{c}\mathbf{8 1 1} \\
(\mathbf{1 0 0 \% )}\end{array}$ & $\begin{array}{c}\mathbf{8 4 2} \\
(\mathbf{1 0 0} \%)\end{array}$ \\
\hline \multicolumn{2}{|c|}{ Table 3: Distribution of Type-2 Diabetic Study Subjects } \\
in Relation to Physical Activity
\end{tabular}

Highest prevalence of type-2 diabetes found among sedentary one, which is $14(45.16 \%)$, then $25.81 \%$ subjects with mild physical activity, $16.13 \%$ moderate physical activity, and $12.90 \%$ whose physical activity is heavy, association is significant after Yates' correction $\mathrm{p}<0.05, \chi^{2}$ test is $10.8908, \mathrm{df}$ was 3 .

\begin{tabular}{|c|c|c|c|}
\hline $\begin{array}{c}\text { Physical } \\
\text { Activity }\end{array}$ & $\begin{array}{c}\text { Impaired Glucose } \\
\text { Tolerance }\end{array}$ & Normal & Total \\
\hline Sedentary & $\begin{array}{c}29 \\
(38.67 \%)\end{array}$ & $\begin{array}{c}209 \\
(25.77 \%)\end{array}$ & $\begin{array}{c}238 \\
(26.86 \%)\end{array}$ \\
\hline Mild & 22 & 365 & 387 \\
$(29.33 \%)$ & $(45.01 \%)$ & $(43.68 \%)$ \\
\hline Moderate & 19 & 203 & 222 \\
$(25.33 \%)$ & $25.03 \%)$ & $(25.06 \%)$ \\
\hline Heavy & $\begin{array}{c}5 \\
(6.67 \%)\end{array}$ & $(4.19 \%)$ & $\begin{array}{c}39 \\
(4.40 \%)\end{array}$ \\
\hline \multirow{2}{*}{ Total } & $\begin{array}{c}\mathbf{7 5} \\
(100 \%)\end{array}$ & $\begin{array}{c}\mathbf{8 1 1} \\
(\mathbf{1 0 0} \%)\end{array}$ & $\begin{array}{c}\mathbf{8 8 6} \\
(\mathbf{1 0 0} \%)\end{array}$ \\
\hline \multicolumn{3}{|c|}{ Table 4: Distribution of Impaired Glucose } \\
Tolerance with Physical Activity \\
\hline \multicolumn{4}{|c|}{}
\end{tabular}

Highest prevalence of Impaired Glucose Tolerance found among people with sedentary life style, which is 29 (38.66\%), then $29.33 \%$ subjects with mild physical activity, $25.33 \%$ moderate physical activity, and $6.66 \%$ whose physical activity is heavy, association is significant $p<0.05, \chi^{2}$ test is 9.068304 , df was 3.

\begin{tabular}{|c|c|c|c|}
\hline $\begin{array}{c}\text { Type of } \\
\text { Diet }\end{array}$ & $\begin{array}{c}\text { Type-2 } \\
\text { DM }\end{array}$ & Normal & Total \\
\hline Vegetarian & $\begin{array}{c}7 \\
(22.58 \%)\end{array}$ & $\begin{array}{c}80 \\
(9.86 \%)\end{array}$ & $\begin{array}{c}87 \\
(10.33 \%)\end{array}$ \\
\hline $\begin{array}{c}\text { Non- } \\
\text { vegetarian }\end{array}$ & $\begin{array}{c}24 \\
(77.42 \%)\end{array}$ & $\begin{array}{c}731 \\
(90.14 \%)\end{array}$ & $\begin{array}{c}755 \\
(89.67 \%)\end{array}$ \\
\hline Total & $\begin{array}{c}31 \\
(100 \%)\end{array}$ & $\begin{array}{c}811 \\
(100 \%)\end{array}$ & $\begin{array}{c}842 \\
(100 \%)\end{array}$ \\
\hline
\end{tabular}

Out of total type-2 diabetic, 7 (22.58\%) are vegetarian and $24(77.42 \%)$ are non-vegetarian, and in total vegetarian $8.05 \%$ has type- 2 diabetes, relation with diet is statistically significant, $(p<0.05), \chi^{2}$ test is 5.2113, df is 1 .

\begin{tabular}{|c|c|c|c|}
\hline Type of Diet & IGT & Normal & Total \\
\hline Vegetarian & $\begin{array}{c}11 \\
(14.67 \%)\end{array}$ & $\begin{array}{c}80 \\
(9.86 \%)\end{array}$ & $\begin{array}{c}91 \\
(10.27 \%)\end{array}$ \\
\hline $\begin{array}{c}\text { Non- } \\
\text { vegetarian }\end{array}$ & $64(85.33 \%)$ & $\begin{array}{c}731 \\
(90.14 \%)\end{array}$ & $\begin{array}{c}795 \\
(89.73 \%)\end{array}$ \\
\hline Total & $\begin{array}{c}\mathbf{7 5} \\
(100 \%)\end{array}$ & $\begin{array}{c}\mathbf{8 1 1} \\
(\mathbf{1 0 0 \% )}\end{array}$ & $\begin{array}{c}\mathbf{8 8 6} \\
\mathbf{( 1 0 0 \% )}\end{array}$ \\
\hline \multicolumn{3}{|c|}{ Table 6: Distribution of IGT Subjects According } \\
to Their Dietary Habit \\
\hline
\end{tabular}

Out of total type-2 diabetic, 11 (14.66\%) are vegetarian and $64(85.33 \%)$ are non-vegetarian and in total vegetarian $12.08 \%$ has type- 2 diabetes, relation with diet is statistically non-significant, ( $\mathrm{p}>0.05), \chi^{2}$ test is 1.13127 , df is 1 .

\begin{tabular}{|c|c|c|c|}
\hline Sex & Type-2 DM & Normal & Total \\
\hline Male & $\begin{array}{c}17 \\
(54.84 \%)\end{array}$ & $\begin{array}{c}407 \\
(50.18 \%)\end{array}$ & $\begin{array}{c}424 \\
(50.36 \%)\end{array}$ \\
\hline Female & $\begin{array}{c}14 \\
(45.16 \%)\end{array}$ & $\begin{array}{c}404 \\
(49.82 \%)\end{array}$ & $\begin{array}{c}418 \\
(49.64 \%)\end{array}$ \\
\hline Total & $\begin{array}{c}\mathbf{3 1} \\
\mathbf{( 1 0 0 \% )}\end{array}$ & $\begin{array}{c}\mathbf{8 1 1} \\
\mathbf{( 1 0 0 \% )}\end{array}$ & $\begin{array}{c}\mathbf{8 4 2} \\
\mathbf{( 1 0 0 \% )}\end{array}$ \\
\hline
\end{tabular}

Table 7: Distribution of Type-2 DM Subjects Sex Wise

Total 17 (54.84\%) male and 14 (45.16\%) female are type2 diabetic. Among total male $4.01 \%$ and female 3.35\% have type- 2 diabetes, association is non-significant ( $p>0.05), \chi^{2}$ test is 0.2586 , df was 1 .

\begin{tabular}{|c|c|c|c|}
\hline Sex & IGT & Normal & Total \\
\hline Male & $\begin{array}{c}43 \\
(57.33 \%)\end{array}$ & $\begin{array}{c}407 \\
(50.18 \%)\end{array}$ & $\begin{array}{c}450 \\
(50.79 \%)\end{array}$ \\
\hline Female & $\begin{array}{c}32 \\
(42.66 \%)\end{array}$ & $\begin{array}{c}404 \\
(49.82 \%)\end{array}$ & $\begin{array}{c}436 \\
(49.21 \%)\end{array}$ \\
\hline Total & $\mathbf{7 5}(100 \%)$ & $\mathbf{8 1 1 ( 1 0 0 \% )}$ & $\mathbf{8 8 6}(100 \%)$ \\
\hline \multicolumn{4}{|c|}{ Table 8: Distribution of IGT Subjects Sex Wise } \\
\hline
\end{tabular}


Total 43 (57.33\%) males and 32 (42.66\%) females are type-2 diabetic. Among, total male $10.1 \%$ and female $7.33 \%$ have IGT, association is non-significant $(p>0.05), \chi^{2}$ test is 0.3732 , df is 1 .

\begin{tabular}{|c|c|c|c|}
\hline $\begin{array}{l}\text { Literacy } \\
\text { Status }\end{array}$ & $\begin{array}{c}\text { Type-2 } \\
\text { DM }\end{array}$ & Normal & Total \\
\hline Illiterate & $\begin{array}{c}9 \\
(29.03 \%)\end{array}$ & $\begin{array}{c}478 \\
(58.94 \%)\end{array}$ & $\begin{array}{c}487 \\
(57.84 \%)\end{array}$ \\
\hline Just literate & $\begin{array}{c}13 \\
(41.94 \%)\end{array}$ & $\begin{array}{c}332 \\
(40.94 \%)\end{array}$ & $\begin{array}{c}345 \\
(40.97 \%)\end{array}$ \\
\hline Primary & $\begin{array}{c}6 \\
(19.35 \%)\end{array}$ & $\begin{array}{c}1 \\
(0.12 \%)\end{array}$ & $\begin{array}{c}7 \\
(0.83 \%)\end{array}$ \\
\hline Secondary & $\begin{array}{c}2 \\
(6.45 \%)\end{array}$ & $\begin{array}{c}0 \\
(0 \%)\end{array}$ & $\begin{array}{c}2 \\
(0.24 \%)\end{array}$ \\
\hline $\begin{array}{l}\text { Higher secondary } \\
\text { and above }\end{array}$ & $\begin{array}{c}1 \\
(3.23 \%)\end{array}$ & $\begin{array}{c}0 \\
(0 \%)\end{array}$ & $\begin{array}{c}1 \\
(0.12 \%)\end{array}$ \\
\hline Total & $\begin{array}{c}31 \\
(100 \%)\end{array}$ & $\begin{array}{c}811 \\
(100 \%)\end{array}$ & $\begin{array}{c}842 \\
(100 \%)\end{array}$ \\
\hline \multicolumn{4}{|c|}{$\begin{array}{c}\text { Table 9: Distribution of Type of Literacy Among Type-2 } \\
\text { Diabetic Abnormal Subjects }\end{array}$} \\
\hline
\end{tabular}

Majority of the subjects in the study group are either illiterate or have low level of literacy. Among total type-2 diabetic, $9(29.03 \%)$ are in the illiterate group, whether 6 $(19.35 \%)$ are up to the primary school, 2 (6.45\%) secondary school, and 1 (3.23\%) in the higher secondary and above literacy group, association of literacy with type-2 diabetes established after Yate's correction $(p<0.001), \chi^{2}$ test is 119.51, $\mathrm{df}$ is 4 .

\section{DISCUSSION}

In this study, $3.38 \%$ and $8.18 \%$ subject were found type-2 diabetes and IGT respectively. Almost similar results 3.67\% diabetes and $5.96 \%$ impaired glucose tolerance were obtained by Kokiwar PR et al in a community-based cross-sectional study. ${ }^{11}$ Anjana RM et al reported in a study that prevalence of diabetes was $10.4 \%$ in Tamilnadu, $8.4 \%$ in Maharashtra, 5.3\% in Jharkhand, and 13.6 in Chandigarh. The prevalence of prediabetes was $8.3 \%, 12.8 \%, 8.1 \%$, and $14.6 \%$ respectively. ${ }^{3}$ In this study, Table- 2 shows that as the age increases, the number of type-2 diabetics also increases, which was found to be statistically significant $(\mathrm{p}<0.005)$. Maximum number of type-2 diabetic subjects belonged to the age group 50-60years.

Patil PS et al reported in their study that as age increases percentage of type- 2 diabetics also increases, which was found statistically significant. ${ }^{12}$ Solanki et al also reported in a study that the prevalence of diabetes mellitus was higher (81.1\%) in persons aged $\geq 40$ years than in persons aged between 20 and 39 years $(18.9 \%) .{ }^{13}$

The results of the present (Table 3 and 4) shows that the diabetes prevalence rate and IGT prevalence is lower in the more active individuals than in the less active individuals. $45.16 \%$ of type- 2 diabetes found in sedentary group and least type- 2 diabetes (12.90\%) was found in individuals with heavy physical activity and the IGT prevalence is also high (38.66\%) in sedentary individuals and least $(2.66 \%)$ in individuals with heavy physical activity.

Different studies showed that a physically active lifestyle is associated with a lower incidence of type-2 diabetes and IGT and its shows that physical activity was inversely related to the prevalence of type- 2 diabetes. Majgi SM et al reported in a study that the prevalence of diabetes is more in people who are engaged in light physical activity work and it was found statistically not significant. ${ }^{14} \mathrm{Ahmad} \mathrm{J}$ et al in study revealed that less physical activity was significantly associated with increased risk for DM. 15

Table 5 and 6 shows that distribution of type- 2 diabetics and IGT is high in non-vegetarians than vegetarians.

In a study, Ayana DA et al reported that the prevalence of type 2 diabetes mellitus was less among those who consumed fruits and vegetables $\geq 3$ days/week as compared to who consumed fruits and vegetables $\leq 2$ days/week. ${ }^{16}$

In Table 7 and 8 shows that the prevalence of type- 2 diabetics and IGT is more in male than female.

Shah C et al and Sahai S et al found in a study the prevalence of IGT was more in male than female.17, 18 In other study, Popescu DS et al reported that the prevalence was higher in females. 19

Table 9 shows the distribution of type- 2 diabetic according to literacy status. Among total type- 2 diabetics, 9 (29.03\%) are in the illiterate group whereas $6(19.35 \%)$ are educated up to the primary school. Higher percentage of type- 2 diabetes and IGT among low literacy groups could be due to their lack of knowledge about nutritive value of different foods, about saturated fat intake and effect of sedentary lifestyle etc.

Majgi SM et al found in a study the prevalence of type-2 diabetes was low in the subject whose education qualification was postsecondary graduate and above. ${ }^{14}$

\section{CONCLUSION}

This study shows that the prevalence of diabetes and IGT is high in the subjects having sedentary lifestyle those who are non-vegetarians and illiterates. So, regular exercise and intake of more fibrous diet, vegetable, fruits can reduce the prevalence of type- 2 diabetes and IGT. This study also shows the high prevalence of type- 2 diabetes and IGT in illiterate and just literate subjects. This may be due to lack of knowledge of nutritive value of food and intake of high saturated fat. So, if we increase in the knowledge and awareness levels about the nutritive value of different food in community can reduce the prevalence of type- 2 diabetes and IGT.

\section{STRENGTH}

The strength of the study was that it was a population-based cross-sectional study to find the prevalence of type-2 DM and IGT among adults in rural area. Bias was taken care of by random sampling. In the present study, an attempt was made to increase the knowledge and awareness level on the hazards of type-2 DM among the study population. The results obtained from this study can be utilized on a broader scale to enhance community awareness about the health consequences of type-2 DM and also to impart some knowledge on the modifiable risk factors of Type-2 DM.

\section{LIMITATIONS}

In spite of the best efforts to convince all the study subjects to participate in the study, some of them did not cooperate. There was difficulty to convince some of the subjects to cooperate in the study and also at time members were not present at their houses, so alternative persons had to be put in place, which required more time. 


\section{RECOMMENDATIONS}

It was also felt during the study that there is a need to increase awareness of type- 2 diabetes mellitus in the general population. Such an awareness programme may develop means for the self-management of diabetes and would be a valuable gain in terms of lesser dependence on outside support.

\section{REFERENCES}

1. Rawal LB, Tapp RJ, Williams ED, et al. Prevention of type 2 diabetes and its complications in developing countries: a review. Int J Behav Med 2012;19(2):121-33.

2. Guariguata L, Whiting DR, Hambleton I, et al. Global estimates of diabetes prevalence for 2013 and projections for 2015. Diabetes Res Clin Pract 2014;103(2):137-49.

3. Anjana RM, Pradeepa R, Deepa M, et al. Prevalence of diabetes and prediabetes (impaired fasting glucose and/or impaired glucose tolerance) in urban and rural India: phase I results of the India council of medical research - India Diabetes (ICMR-INDIAB) study. Diabetology 2011;54(12):3022-7.

4. Danaei G, Finucane MM, Lu Y, et al. National, regional and global trends in fasting plasma glucose and diabetes prevalence since 1980: systematic analysis of health examination surveys and epidemiological studies with 370 country years and 2.7 million participants. Lancet 2011;378(9785):31-40.

5. Al-Razzuqi RAM, Al-Jeboori AA. Is glucosaminechondroitin risky to normoglycemic individuals with family history of diabetes mellitus ? International Journal of Diabetes in Developing Countries 2011;31(1):37-40.

6. Jorgensen ME, Borch-Johnsen K, Witte DR, et al. Diabetes in Greenland and its relationship with urbanization. Diabet Med 2012;29(6):755-60.

7. Sosale A, Prasanna Kumar KM, Sadikot SM, et al. Chronic complication in newly diagnosed patients with type 2 diabetes mellitus in India. Indian J Endocrinol Metab 2014;18(3):355-60.

8. Unnikrishnan R, Anjana RM, Mohan V. Diabetes in South Asians: is the phenotype different? Diabetes 2014;63 (1): 53-5.
9. Mohan V, Shah S, Saboo B. Current glycaemic status and diabetes related complications among type 2 diabetes patients in India: data from the A1chieve study. JAPI 2013;61(Suppl 1):12-5.

10. Mohan V, Seshiah V, Sahay BK, et al. Current status of management of diabetes and glycaemic control in India: preliminary results from the diabcare India 2011 study. Diabetes 2012;61:a645-77.

11. Kokiwar PR, Gupta S, Durge PM. Prevalence of diabetes in rural area of central India. Int J Diab Dev Ctries 2007;27(1):8-10.

12. Patil PS, Dixit UR, Hiralal BD. Study of diabetes in Dharwad-an urban area in India. Indian Journal of Science and Technology 2011;4(11):1481-3.

13. Niti S, Amrit V, Gupta BP, et al. Prevalence and risk factor diabetes mellitus among adults residing in field practice area of a teaching hospital in Punjab. Healthline 2015;6(1):57-62.

14. Majgi SM, Soudarssanane BM, Roy G, et al. Risk factors of diabetes mellitus in rural Puducherry. Online J Health Allied Scs 2012;11(1):4.

15. Ahmad J, Masoodi MA, Ashraf M, et al. Prevalence of diabetes mellitus and its associated risk factors in age group of 20 years and above in Kashmir, India. Al Ameen J Med Sci 2011;4(1):38-44.

16. Ayana DA, Bacha YD, Roba KT, et al. Type 2 diabetes mellitus among government employees in Harar, eastern Ethiopia: a cross-sectional study. Research and Report in Endocrine Disorders 2015;5:71-7.

17. Shah C, Sheth NR, Solanki B, et al. To assess the prevalence of impaired glucose tolerance and impaired fasting glucose in western Indian population. JAPI 2013;61:23-8.

18. Sahai S, Vyas D, Sharma S. Impaired fasting glucose: a study of its prevalence documented at a tertiary care centre of central India and its association with anthropometric variables. JIACM 2011;12(3):187-92.

19. Popescu DS, Ciobica A, Arhire LI, et al. Increased prevalence of impaired glucose tolerance in a representative rural population from Deleni, Romania. Arch Biol Sci Belgrade 2013;65(4):1579-84. 